\title{
BANK WAKAF MIKRO SEBAGAI SARANA PEMBERDAYAAN PADA USAHA MIKRO, KECIL DAN MENENGAH
}

\author{
Wizna Gania Balqis dan Tulus Sartono \\ Fakultas Hukum Universitas Diponegoro Semarang \\ Email:wzngania@gmail.com
}

\section{Abstract}

The financial institution in Indonesia has growth significantly. However, there are people who still have difficulty in accessing these institutions. Wakaf Micro Bank is an Islamic microfinance institution focusing on financing small communities with profit sharing. This institution is purely for financing. The fund are gathered from people's, institutions', and corporations' donation through the National Amil Zakat Institution (LAZNAS). This institution is founded due to the difficulty access of the Micro, Small and Medium Enterprises (MSME) in finding financial source to encourage economic growth. This study explains the working mechanism of Wakaf Micro Bank in empowering MSMEs and the contracts used by Wakaf Micro Bank in Islamic boarding schools. This study uses empirical legal research using qualitative approach. The results show that the financing mechanism of Wakaf Micro Bank is group-based and the profit obtained is 3\% without collateral. Transactions in Islamic financial institutions must use contracts that are in accordance with Islamic values.

Perkembangan lembaga keuangan di Indonesia dewasa ini, telah mengalami pertumbuhan yang signifikan. Namun, masih terdapat masyarakat yang kesulitan dalam mengakses lembaga keuangan tersebut. Hadirnya Bank Wakaf Mikro merupakan lembaga kenangan mikro syariah yang fokus pada pembiayaan masyarakat kecil dengan pola bagi hasil, serta lembaga ini murni untuk pembiayaan. Dana yang digunakan berasal donasi dari perseorangan, lembaga maupun korporasi melalui Lembaga Amil Zakat Nasional (LAZNAS). Latar belakang didirikannya Bank. Wakaf Mikro adalah karena sulitnya akses permodalan terhadap sektor Usaba Mikro, Kecil dan Menengah (UMKM) guna mendorong pertumbuban ekonomi. Tujuan penelitian ini adalah untuk menjelaskan tentang mekanisme kerja Bank Wakaf Mikro dalam pemberdayaan pada UMKM dan akad yang digunakan pada Bank Wakaf Mikro di lingkungan pondok pesantren. Penelitian ini menggunakan penelitian bukum empiris dengan menggunakan pendekatan kualitatif. Hasilpenelitian menunjuk.kan 
bahwa mekanisme pembiayaannya Bank. Wakaf Mikero berbasis kelompok dan imbal hasil yang didapat sebesar 3\% tanpa agunan. Transaksi dalam lembaga keuangan syariah harus menggunakan akad yang sesuai dengan nilai-nilai syariah.

Keywords: Wakaf Micro Bank, empowering, wakaf

\section{Pendahuluan}

Wakaf sebagai salah satu sumber dana yang mempunyai potensi dalam pengembangan ekonomi umat. Selain itu, wakaf dapat memberikan manfaat dalam kesejahteraan masyarakat sebagai dana abadi umat. ${ }^{1}$ Seperti halnya yang diatur dalam Undang-Undang No. 41 Tahun 2004 tentang Wakaf dimana wakaf mempunyai tujuan untuk memberdayaan kemashalahatan dan kesejahteraan sosial secara produktif. Fungsi dari wakaf adalah sebagai pilar ekonomi, sehingga diharapkan bisa terus memberikan bantuan pembiayaan kepada pengusaha kecil. ${ }^{2}$ Sebagai negara dengan mayoritas penduduk beragama Islam, Indonesia mempunyai potensi wakaf uang yang terbilang sangat besar.Tetapi pada kenyataanya belum bisa dikembangkan secara maksimal. ${ }^{3}$

Fungsi dan tujuan didirikannya sebuah negara salah satunya untuk menciptakan kesejahteraan dan kemakmuran yang sebesar-besarnya bagi rakyatnya. ${ }^{4}$ Keberhasilan suatu negara dapat tergambarkan dari seberapa sejahtera dan makmur rakyatnya. Kesejahteraan dan kemamkmuran dapat dicapai melalui tatanan ekonomi nasional, tatanan ekonomi nasional tersebut salah satunya tercermin dengan adanya Usaha Mikro, Kecil, dan Menengah (UMKM) yang merupakan bentuk organisasi ekonomi yang sejalan dengan sistem ekonomi kerakyatan atau demokrasi ekonomi. Dalam pembangunan ekonomi nasional, UMKM memiliki peran yang strategis, mengingat bahwa tingkat kemiskinan dan pengangguran di Indonesia dimana setiap tahunnya semakin meningkat maka UMKM dapat menambah lapangan pekerjaan yang dapat menurunkan tingkat pengangguran di Indonesia, oleh karena itu akan memberikan efek yang besar terhadap aktivitas perekonomian secara makro.

Disamping mempunyai peranan yang penting dalam perekonomian nasional, dalam menjalankan bisnisnya sektor UMKM mempunyai berbagai tantangan

1 Fuadi, N. F.Z. "Wakaf Sebagai Instrumen Ekonomi Pembangunan Islam," Jurnal Ekonomi Islam Vol 9, No 1, Tahun 2018, h. 152.

2 Mahat, M. A, Jaaffar, M. Y, dan Rasool, M. S. A. "Potential of Micro-Waqf as an Inclusive Stratagy for Development of Nation. "Procedia Economics and Finance, Tahun 2015, h. 296.

3 Medias, F. "Bank Wakaf: Solusi Pemberdayaan Sosial Ekonomi Indonesia," Indonesian Journal of Islamic Literature and Muslim Society, Vol. 2, No. 1, Tahun 2017, h. 63.

4 Disemadi, H.S., \& Roisah, K. "Kontrak Build Operate Transfer Sebagai Sarana Mewujudkan Kesejahteraan Rakyat”. Jurnal Komunikasi Hukum, Vol.5, No.2, Tahun 2019, h. 127 
salah satunya mengenai kurangnya ilmu pengetahuan dan keterampilan yang dimiliki oleh sumber daya manusia dalam mengembangkan usahanya, masalah pada permodalan dan kurangnya sarana dan prasarana terhadap akses pemasaran produknya.5 Sulitnya akses permodalan terhadap sektor UMKM tersebut, mengharuskan lahirnya inisiatif dari pemerintah untuk mendorong pertumbuhan ekonomi. Bank Wakaf Mikro (BWM) merupakan jawaban dari sulitnya permodalan diatas. Lahirnya Bank Wakaf Mikro dinisiasi oleh Otoritas Jasa Keuangan (OJK) dan Lembaga Amil Zakat Nasional (Laznas). Pada tanggal 18 Desember 2018, Wimboh Santoso selaku Komisioner OJK menyebutkan sudah terdapat 41 Bank Wakaf Mikro yang telah berdiri di Indonesia. ${ }^{6}$ Salah satunya adalah Bank Wakaf Mikro Amanah Berkah Sejahtera di Pondok Pesantren Al Hidayah Karang Suci yang berada di Purwokerto.

Lembaga Keuangan Mikro masih menjadi bagian penting dalam sistem perekonomian di Indonesia karena cakupan usaha di sektor mikro dan kecil masih sangat tinggi. ${ }^{7}$ Dengan berdirinya Bank Wakaf Mikro dapat meningkatkan akses keuangan masyarakat pada tingkat mikro untuk memudahkan pelaku UMKM dalam masalah permodalan. ${ }^{8}$ Bank Wakaf Mikro merupakan lembaga keuangan mikro syariah yang fokus pada pembiayaan masyarakat kecil dengan pola bagi hasil, serta lembaga ini murni untuk pembiayaan. Dana yang digunakan berasal donasi dari perseorangan, lembaga maupun korporasi melalui Lembaga Amil Zakat Nasional (LAZNAS). ${ }^{9}$ Bank Wakaf Mikro juga memfasilitasi dalam hal penyediaan dana yang dapat membantu pihak-pihak yang membutuhkan dana untuk memenuhi kebutuhannya. pihak-pihak yang membutuhkan dana yaitu masyarakat di lingkungan sekitar pondok pesantren, karena pondok pesantren merupakan salah satu elemen masyarakat yang mempunyai fungsi strategis dalam pendampingan demi mendorong perekonomian masyarakat. ${ }^{10}$ Yang menjadi

5 Disemadi, H.S, \& Wahyuni, R.A.E. “Eksistensi Dan Kebijakan Regulasi Perizinan Lembaga Keuangan Mikro Oleh Otoritas Jasa Keuangan”, Vol.3, No.2, Tahun 2019, h. 118

6 Kompas.com, Hingga Desember 2018 OJK Terbitkan 41 Bank Wakaf Mikero, https: / / ekonomi. kompas.com/read/2018/12/18/190548926/hingga-desember-2018-ojk-terbitkan-izin-41bank-wakaf-mikro Diakses pada tanggal 17 Mei Tahun 2019, pukul 14.03

7 Gustani dan Ernawan, D. A, "Wakaf Tunai sebagai Sumber Alternatif Permodalan Lembaga Keuangan Mikro Syariah di Indonesia," Journal of Islamic Economics Lariba, Vol. 2, No. 1, Tahun 2016, h. 39.

8 Faujiah, A, "Bank Wakaf Mikro dan Pengaruhnya terhadap Inklusi Keuangan Pelaku Usaha Kecil dan Mikro (UKM)," 2nd Proceedings Annual Conference for Muslim Scholars, Tahun 2018, h. 375.

9 Infobanknews.com, Bank Wakaf Mikero: Fokus Pada Pembiayaan Masyarakat Kecil, http:/ / infobanknews.com/bank-wakaf-mikro-fokus-pada-pembiayaan-masyarakat-kecil/ Diakses pada tanggal 16 Mei Tahun 2019, Pukul 13.48

10 Faujiah, A. op.cit, h. 655. 
sasaran dalam pembiayaan Bank Wakaf Mikro adalah masyarakat kecil potensial produktif agar kesejahteraan ekonomi masyarakat yang berada di lingkungan sekitar pondok pesantren dapat meningkat.

Bank Wakaf Mikro sebagai Lembaga Keuangan Syariah (LKMS) dapat dijadikan sebagai solusi alternatif dalam meningkatkan perekonomian bangsa Indonesia dimana dapat dilihat bahwa mayoritas masyarakat Indonesia bergerak di bidang Usaha Mikro Kecil dan Menengah. Hal ini dilatarbelakangi karena Lembaga Keuangan Syariah di nilai lebih fleksibel dan dapat menjangkau masyarakat kecil dibandingkan dengan bank-bank lain yang hanya bisa menjangkau kalangan menengah ke atas saja. ${ }^{11}$ Selain itu, adanya Bank Wakaf Mikro sebagai Lembaga Keuangan Syariah diharapkan dapat juga dijadikan sebagai solusi alternative untuk masyarakat agar terhindar dari praktik riba yang banyak diterapkan oleh para rentenir dan bank-bank konvensional yang berada di sekitar lingkungan tempat tinggal. Dengan solusi-solusi inilah diharapkan dapat digantikan dengan prinsip-prinsip muamalah sesuai dengan syariah dalam ajaran agama Islam karena Lembaga Keuangan Syariah sudah pasti menjunjung tinggi asas-asas dan nilainilai syariah.

Berdasarkan uraian yang dikemukakan diatas, dapat dirumuskan dua permasalahan, yang perlu dikaji, yaitu: pertama, bagaimana mekanisme operasional Bank Wakaf Mikro sebagai sarana pemberdayaan pada UMKM dan yang kedua, bagaimana bentuk akad yang digunakan Bank Wakaf Mikro di lingkungan pondok pesantren.

\section{Metode Penelitian}

Permasalahan yang telah dirumuskan di atas akan dijawab atau dipecahkan dengan menggunakan metode pendekatan yuridis empiris. Pendekatan yuridis empiris dalam penelitian ini maksudnya adalah bahwa dalam menganalisis permasalahan dilakukan dengan cara memadukan bahan-bahan hukum (yang merupakan data sekunder) dengan data primer yang diperoleh di lapangan. Pendekatan yuridis (hukum dilihat sebagai norma atau das sollen), karena dalam membahas permasalahan penelitian ini menggunakan bahan-bahan hukum baik hukum yang tertulis maupun hukum yang tidak tertulis atau baik bahan hukum primer maupun bahan hukum sekunder.

Berkaitan dengan jenis penelitian yang digunakan, maka data yang digunakan dalam penelitian ini meliputi data primer yakni data yang diperoleh melalui penelitian

11 A. S. Rusydiana \& Irman Firmansyah, Strategi Pengembangan Lembaga Keuangan Mikro Syariah di Indonesia: Pendekatan Matriks EFAS IFES, Jurnal Ekonomi Islam, Vol. 9 No. 1, Tahun 2018, h. 65. 
langsung dari lapangan. Data primer didapat dari sumber pertama, yaitu: (1) Bank Wakaf Mikro Amanah Berkah Nusantara di Pondok Pesantren Al Hidayah Karang Suci di Purwokerto; kedua, (2) Masyarakat produktif yang bertempat tinggal di sekitar lingkungan Pondok Pesantren Al Hidayah Karang Suci Purwokerto. Data primer diperoleh dengan menggunakan metode wawancara dengan teknik non random sampling, dimana responden yang berkaitan dengan masalah yang akan diteliti dalam penelitian ini sudah ditentukan terlebih dahulu. Responden dalam penelitian ini adalah pengurus dan anggota Bank Wakaf Mikro Amanah Berkah Nusantara di Pondok Pesantren Al Hidayah Karang Suci di Purwokerto.

Selain menggunakan data primer, penelitian ini juga menggunakan data sekunder. Data sekunder yaitu data yang dibersumber dari bahan-bahan kepustakaan guna menemukan landasan teoritis berupa peraturan perundangundangan maupun literature atau bahan pustaka yang berkaitan dengan masalah dalam penelitian ini. Data sekunder yang digunakan dalam penelitian ini meliputi aturan perundang-undangan seperti Undang-Undang No. 41 Tahun 2004 tentang Wakaf; Undang-Undang No. 1 Tahun 2013 tentang Lembaga Keuangan Mikro; Peraturan Otoritas Jasa Keuangan (OJK) No. 62/POJK.05/2015; Peraturan Bank Indonesia No. 7/46/PBI/2005 tentang Akad Penghimpunan dan Penyaluran Dana bagi Bank yang Melaksanakan Kegiatan Usaha berdasarkan Prinsip syariah; dan Fatwa MUI No. 19/DSN-MUI/XI/2000 tentang Qardh.

Data primer dan data sekunder yang telah diperoleh dalam penelitian ini selanjutnya akan dianalisis menggunakan analisis deskriptif kualitatif. Penelitian deskriptif menekankan pada adanya penemuan fakta-fakta yang digambarkan sebagaimana keadaan sebenarnya dan selanjutnya data maupun fakta tersebut kemudian di olah dan ditafsirkan dengan maksud guna memberikan data yang detail dan akurat tentang objek yang diteliti yakni keberadaan Bank Wakaf Mikro sebagai sarana dalam pemberdayaan UMKM. ${ }^{12}$ Sedangkan analisis kualtitatif yaitu proses dalam penyusunan, pengkategorian data kualitatif, serta dengan mencari pola atau tema yang dimaksud untuk memahami maknanya. Penelitian ini diharapkan dapat memberikan fakta secara rinci, sistematis dan menyeluruh yang selanjutnya akan dianalisis menggunakan peraturan perundang-undangan yang berlaku sehingga dapat diperoleh gambaran mengenai keberadaan Bank Wakaf Mikro sebagai sarana dalam pemberdayaan pada Usaha Kecil, Mikro dan Menengah (UMKM). Selanjutnya hasil dari analisis data tersebut akan disajikan secara deskriptif yaitu dengan mengarahkan dan menggambarkan secara apa

12 Satcipto Rahardjo, Ilmu Hukum, (Bandung: Alumni, 1996), h. 35. 
adanya sesuai dengan permasalahan yang akan diteliti. ${ }^{13}$

\section{Pembahasan}

Mekanisme Operasional Bank Wakaf Mikro Sebagai Sarana Pemberdayaan Pada Usaha Mikro, Kecil Dan Menengah (UMKM).

Bank Wakaf Mikro merupakan upaya pemerintah untuk meningkatkan inklusi keuangan bagi masyarakat melalui pemberian akses jasa keuangan formal dimana hal tersebut merupakan pelaksanaan dari Peraturan Presiden Republik Indonesia Nomor 82 Tahun 2016 tentang Strategi Nasional Keuangan Inklusif. Bank Wakaf Mikro merupakan Lembaga Keuangan non Bank. Dalam hal ini, OJK berfokus dalam menyediakan akses keuangan untuk masyarakat luas dan ikut berpartisipasi dalam mendukung program yang diselenggarakan oleh pemerintah. Program ini dimaksudkan untuk mengatasi masalah pemberantasan kemiskinan dan ketimpangan melalui financial inclusion yang diwujudkan dalam bentuk inovasi model bisnis Lembaga Keuangan Mikro (LKM) Syariah-Pesantren. Dimana fokusnya adalah pada kalangan masyarakat kecil. Ijin operasional Bank Wakaf Mikro berada dibawah OJK dan diatur dalam Undang-Undang Nomor 1 Tahun 2013 tentang Lembaga Keuangan Mikro Pasal 9. Namun pada bulan Juni 2018, Ah. Azharuddin Lathif M.H., M.Ag., selaku Dewan Pengawas Syariah mengatakan bahwa sampai saat ini DSN-MUI belum pernah mengeluarkan fatwa tentang pedoman untuk pendirian dan mekanisme kerja Bank Wakaf Mikro. ${ }^{14}$

Lembaga Keuangan Mikro merupakan lembaga keuangan yang didirikan khusus guna memberikan jasa pengembangan usaha dan pemberdayaan masyarakat, baik itu melalui pinjaman ataupun pembiayaan dalam usaha berskala mikro terhadap anggota dan masyarakatnya, sebagai pengelolaan simpanan maupun dapat memberikan jasa konsultasi dalam hal pengembangan usaha dan tidak semata-mata hanya mencari keuntungannya saja. Hal ini sesuai dengan definisi Lembaga Keuangan Mikro yang tercantum dalam Undang-Undang No 1 Tahun 2013 tentang Lembaga Keuangan Mikro. Tujuan dibentuknya Lembaga Keuangan Mikro dibentuk sesuai dengan tujuan yang terdapat dalam Undang-Undang No. 1 Tahun 2013 tentang Lembaga Keuangan Mikro yang dalam Pasal 3 menyebutkan mengenai pemberian jasa pengembangan usaha serta pemberdayaan masyarakat melalui pinjaman dan pembiayaan untuk usaha skala mikro kepada anggota masyarakat. Target sasaran

13 H. B. Sutopo, Metodologi Penelitian Hukum Kualitatif Bagian II, (Surakarta: UNS Press, 1998), h. 37.

14 Sharianews.com. Az̧aruddin Lathif: DSN Belum Pernab Keluarkan Fatwa Pedoman Bank. Wakaf Mikro, https://sharianews.com/posts/azharuddin-lathif-dsn-belum-pernah-keluarkan-fatwapedoman-bank-wakaf-mikro Diakses pada tanggal 19 Mei Tahun 2019, Pukul 16.24 
OJK adalah masyarakat kecil yang bertempat tinggal di sekitar pondok pesantren yang mempunyai kemauan dan semangat untuk bekerja.

Pondok Pesantren dijadikan lembaga yang potensial bagi masyarakat selain menjadi lembaga pendidikan umat Islam namun juga menjadi lembaga pemberdayaan. Keterlibatan Pondok Pesantren yang dengan aktifguna memberdayakan masyarakatnya merupakan suatu wujud komitmen yang diberikan oleh Pondok Pesantren kepada masyarakat di sekitar lingkungan Pondok Pesantren guna meningkatkan perekonomian masyarakatnya, baik individu maupun kelompok. Tujuannya adalah agar tingkat sumber daya dapat tercapai secara optimal sehingga kesejahteraan masyarakatnya dapat meningkat dan mutu masyarakat yang bertumpu pada kemandirian. Hal tersebut telah sesuai dengan panduan program yang dibuat oleh Otoritas Jasa Keuangan (OJK) mengenai kriteria yang menjadi sasaran dalam program Bank Wakaf Mikro yakni segmentasi nasabah selaku penerima pembiayaan dari Bank Wakaf Mikro adalah masyarakat yang memiliki potensi usaha dengan radius 5 (lima) kilometer dari lokasi Bank Wakaf Mikro.

Bank Wakaf Mikro melakukan kegiatan usaha meliputi pengembangan usaha dan pemberdayaan masyarakat, menyediakan produk pembiayaan dan pendampingan usaha, serta pemberian jasa konsultasi pengembangan usaha pada skala usaha mikro. Hal ini sesuai dengan apa yang dijelaskan dala Pasal 11 UndangUndang Nomor 1Tahun 2013. Yang menjadikan karakteristik Bank Wakaf Mikro berbeda dibandingkan dengan lembaga keuangan lainnya adalah Bank Wakaf Mikro hanya menyalurkan dana, tidak melakukan kegiatan penghimpunan dana, mekanisme pembiayaannya berbasis kelompok dan imbal hasil yang didapat sebesar 3\% tanpa agunan.

Dalam pelaksanaannya, dana yang menjadi modal dasar Bank Wakaf Mikro untuk pembiayaan mikro pada masyarakat kecil produktif yang berada di sekitar lingkungan pondok pesantren berasal dari dana donator, yang menjadi donatur yakni bisa berasal dari semua kalangan atau korporasi. Dana donator tersebut merupakan dana yang dihimpun oleh Lembaga Amil Zakat Nasional (Laznas). Disamping itu, Laznas juga memfasilitasi dalam pendampingan kepada nasabah Bank Wakaf Mikro meliputi pendampingan usaha, pendampingan manajemen ekonomi rumah tangga, serta pendampingan agama yang dilakukan secara berkala. Bank Wakaf Mikro mendapatkan bantuan dana dari donatur sebesar Rp. 3.000.000.000 (Tiga miliar rupiah) sampai dengan Rp. 4.000.000.000 (Empat miliar rupiah). Akan tetapi dana tersebut tidak semuanya akan digunakan pada pembiayaan melainkan sebagian akan disimpan dalam bentuk deposito di Bank Umum Syariah. Dana kemudian disalurkan dalam bentuk tunai kepada nasabahnya 
dimana setiap nasabah mendapatkan dana pembiayaan awal dengan nominal sebesar Rp.1000.000 (Satu juta rupiah) dan hanya dikenakan beban margin bagi hasil sebesar 3\% untuk keperluan operasional. Angka tersebut terbilang sangat kecil untuk skala lembaga keuangan. ${ }^{15}$ Pembiayaan dalam Bank Wakaf Mikro fokus terhadap pelaku usaha serta untuk modal kegiatan usaha.

Selain dana sebesar Rp. 4.000.000.000 (empat miliar rupiah) sebagai dana yang digunakan dalam kegiatan usaha Bank Wakaf Mikro, Bank Wakaf Mikro juga mendapatkan sumbangan dana bantuan dari LAZ BSM sebesar Rp. 250.000.000 (dua ratus lima puluh juta rupiah) yang digunakan untuk kebutuhan pendirian Bank Wakaf Mikro meliputi juga pendirian bangunan dan ijin usaha. Pencairan dana yang berasal dari sumbangan dana bantuan oleh LAZ BSM tersebut hanya dapat dicairkan dengan cara mengajukan permohonan pencairan deposito ke tabungan lembaga yang kemudian disalurkan kepada LAZ BSM. Setelah proses pengajuan permohonan berikut berkas-berkas dokumen calon nasabah dinyatakan sudah lengkap, maka akan dilaporkan pada pihak Otoritas Jasa Keuangan (OJK). Dana yang sudah dicairkan tersebut kemudian akan disimpan di tabungan atas nama Bank Wakaf Mikro. Pencairan dana tersebut harus didampingi oleh manager, bendahara dan bagian administrasi dari Bank Wakaf Mikro tersebut. ${ }^{16}$

Mekanisme operasional dalam Bank Wakaf Mikro bersifat tanggung renteng antar anggotanya. Tanggung renteng yang dimaksud adalah apabila hija nasabah belum sanggup untuk membayar angsuran dana yang telah dipinjam pada saat dilakukan cicilan pembayaran maka anggota lain yang satu kelompok dengannya akan menanggung terlebih dahalu. Mekanisme operasional Bank Wakaf Mikro diawali dengan calon nasabah akan diseleksi terlebih dahulu kemudian setelah menjadi nasabah, ketika akan mengajukan pembiayaan pada Bank Wakaf Mikro mereka membuat suatu perkumpulan kelompok yang mereka sebut sebagai 'Kumpi”. Kumpi berasal dari singkatan Kelompok Usaha Masyarakat di sekitar Pesantren. Dalam satu Kumpi terdapat 5 (Lima) orang anggota. Setelah itu Kumpi mengadakan pertemuan antar Kumpi lainnya dimana kegiatan ini mereka sebut sebagai "Halmi" kegiatan tersebut dalam hal untuk pencairan dan cicilan dana pembiayaan yang diberikan oleh Bank Wakaf Mikro kepada tiap anggota Kumpi. Halmi dilakukan pada tiap minggunya selama setahun dengan total 50 (Lima puluh) kali pertemuan antar anggota Kumpi. Dalam menjalankan operasional kegiatan usahanya, Bank Wakaf Mikro diawasi oleh OJK yang berkoordinasi dengan pondok pesantren,

15 Badan Wakaf Indonesia. OJK-Pesantren dirikan Bank Wakaf Mikro, apa itu?. https://bwi.or.id/ index.php/en/publikasi/news/1741-ojk-pesantren-dirikan-bank-wakaf-mikro-apa-itu.html

16 Wawancara dengan Ibu Wiwik selaku Asisten Manager Bank Wakaf Mikro Amanah Berkah Nusantara pada Tanggal 30 Agustus Tahun 2019 
perangkat desa, serta pemerintah daerah setempat. Pembiayaan dalam mekanisme opersional yang dilakukan oleh Bank Wakaf Mikro berbasis pembiayaan syariah dimana harus patuh pada prinsip-prinsip syariah yaitu melarang adanya unsur riba, gharar, maisyir, haram dan dzalim didalamnya. Mekanisme operasional Bank Wakaf Mikro dapat digambarkan dengan skema sebagai berikut:

\section{Gambar 1. Mekanisme Operasional Bank Wakaf Mikro}

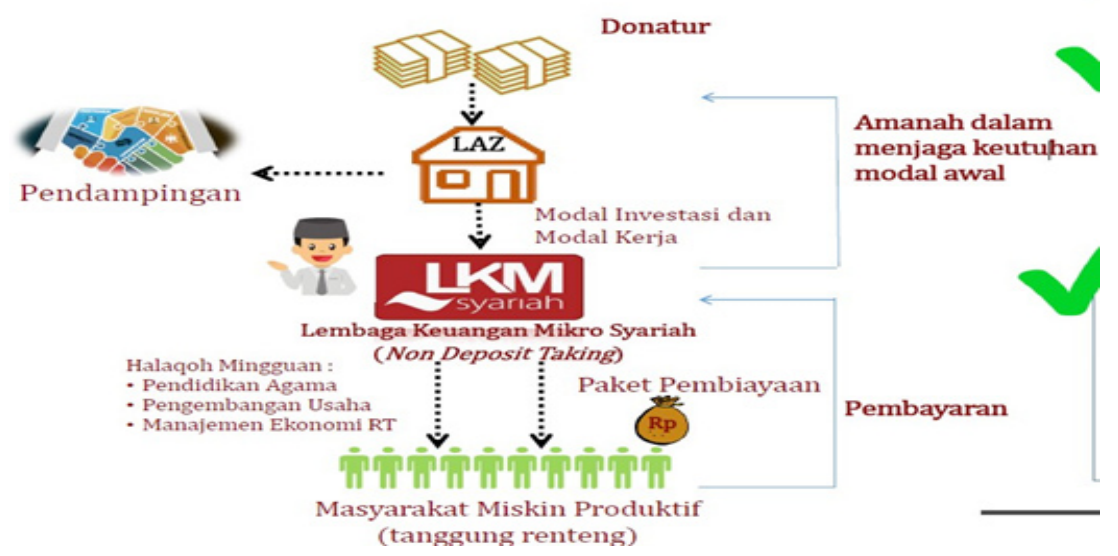

Sumber: Otoritas Jasa Keuangan

\section{Model Pembiayaan Dalam Bank Wakaf Mikro Di Lingkungan Pondok Pesantren.}

Undang-Undang Nomor 1 Tahun 2013 tentang Lembaga Keuangan Mikro, memberikan definisi mengenai Lembaga Keuangan Mikro yakni suatu lembaga keuangan yang didirikan guna memberikan jasa berupa pengembangan usaha dan pemberdayaan masyarakat, dimana dalam hal ini suatu pemberiaan pembiayaan tersebut merupakan salah satu bentuk dari kegiatan yang dilaksanakan oleh Lembaga Keuangan Mikro. Di Indonesia, pembiayaan dalam ruang lingkup perbankan dibedakan menjadi 2 model yakni pertama pembiayaan dengan basis konvensional, dimana pembiayaan konvensional ini berbasis pada imbalan dalam bentuk bunga. Sedangkan kedua pembiayaan dengan basis syariah, dimana pembiayaan syariah ini berbasis pada nilai-nilai syariah agar terhindar dari adanya unsur-unsur seperti riba, gharar, dan maisyir.

Pembiayaan merupakan elemen penting dalam aktivitas Bank Syariah dalam penyaluran dana kepada nasabah yang berdasarkan prinsip-prinsip syariah. Penyaluran dana yang dilakukan dalam bentuk pembiayaan ini didasari oleh adanya 
rasa kepercayaan yang diberikan oleh si pemilik dana kepada si penerima dana. Maksudnya adalah si pemilik dana harus percaya bahwa dana yang diberikan kepada si penerima dana dalam bentuk pembiayaan tadi pasti akan terbayar. Disamping penerima dana mendapatkan kepercayaan dari si pemilik dana, penerima dana juga berkewajiban untuk mengembalikan pembiayaan yang telah diterimanya sesuai dengan jangka waktu yang telah disepakati pada saat akad pembiayaan. Fungsi dari pembiayaan yang diberikan oleh lembaga keuangan ini untuk membantu masyarakat dalam pemenuhan kebutuhan dan peningkatan usahanya. Dalam hal ini masyarakat yang dimaksud adalah individu, pengusaha, lembaga, badan usaha, dan lain-lain yang membutuhkan dana.

Dalam catatan Otoritas Jasa Keuangan, sampai saat ini pendirian Bank Wakaf Mikro semakin mengalami peningkatan. Seperti yang sudah dijelaskan sebelumnya bahwa Bank Wakaf Mikro melakukan kegiatan usaha dengan permodalan atau pembiayaan kepada masyarakat kecil khususnya masyarakat yang berada di lingkungan Pondok Pesantren. Kegiatan usaha ini dilakukan dengan cara pelatihan dan pendampingan dengan maksud agar para anggota atau para nasabahnya dapat berkembang dan lebih produktif. Keberadaan Bank Wakaf Mikro masih mempunyai banyak pertimbangan, namun bagaimanapun keadaannya Bank Wakaf Mikro harus tetap berjalan sesuai dengan tujuan yang hendak dicapai walaupun biaya opersional masih minimal.

Dewan Syariah Nasional Majelis Ulama Indonesia (DSN-MUI) sampai saat ini juga belum memberikan Fatwa mengenai Bank Wakaf Mikro. Hal itu diperjelas oleh Azharaddin selaku Dewan Pengawas Syariah yang mengatakan bahwa alasan DSN-MUI belum memberikan fatwa mengenai Bank Wakaf Mikro adalah karena pihak OJK sampai saat ini belum mengajukan permohonan kepada pihaknya. ${ }^{17}$ Sehingga belum jelas mengenai model pelaksanaan Bank Wakaf Mikro. Seharusnya OJK harus segera mengajukan permohonan fatwa kepada DSN-MUI mengenai Bank Wakaf Mikro ini. Tujuannya agar tidak menimbulkan kesimpangsiuran mengenai model dan prinsip baik dari sisi pendirian, sumber dana opersional, akad yang digunakan dalam pelaksanaanya sesuai dengan prinsipprinsip syariah. Namun pada dasarnya transaksi dalam lembaga keuangan syariah harus menggunakan akad yang sesuai dengan nilai-nilai syariah. Dalam Peraturan OJK No. 62/POJK.05/2015 menyebutkan bahwa akad-akad yang bisa digunakan dalam Lembaga Keuangan Mikro Syariah adalah akad mudharabah, musyarakah,

17 Sharianews.com. Agar tidak. Memicu Polemik, OJK bisa Minta Fatwa tentang Bank Wakaf Mikro ke DSN. https://sharianews.com/posts/agar-tidak-memicu-polemik-ojk-bisa-minta-fatwatentang-bank-wakaf-mikro-ke-dsn Diakses pada tanggal 20 Mei Tahun 2019 Pukul 8.25 
murabahah, ijarah, salam, isthisna, ijarah muntahiya bittamlik dan qardh.

Penulis akan mencontohkan model akad yang digunakan pada Bank Wakaf Mikro Amanah Berkah Nusantara di Pondok Pesantren Al Hidayah Karang Suci yang berada di Purwokerto. Model akad pembiayaan yang digunakan oleh Bank Wakaf Mikro ini yaitu menggunakan Akad Qardh. ${ }^{18}$ Qardh secara terminology adalah memberikan harta kepada seseorang yang akan mengambil manfaat dari harta tersebut dan mengembalikan gantinya pada kemudian hari. ${ }^{19}$ Adapun menurut ketentuan Bank Indonesia Pasal 1 angka 11 Peraturan Bank Indonesia Nomor 7/46/PBI/2005 tentang Akad Penghimpunan dan Penyaluran Dana bagi Bank yang Melaksanakan Kegiatan Usaha berdasarkan Prinsip syariah, mengartikan Qardh adalah kegiatan pinjam meminjam dana yang dilakukan tanpa imbalan (tanpa bunga) dengan kewajiban pihak peminjam mengembalikan pokok pinjaman secara sekaligus atau dengan cicilan dalam jangka waktu tertentu. Jadi dalam hal ini Bank Wakaf Mikro tidak boleh mengambil profit atau keuntungan atas pinjaman yang diberikan kepada nasabahnya, sebab tujuan Bank Wakaf Mikro adalah untuk kemashlahatan umat. ${ }^{20}$

Pembiayaan dengan menggunakan akad Qardh diperbolehkan dan telah disepakati oleh para ulama. Kesepakatan yang diberikan oleh para ulama ini dilandasi oleh tabiat manusia sebagai makhluk sosial yang tidak akan bisa hidup tanpa pertolongan dari manusia lainnya. Tidak akan pernah ada seorang pun yang dapat memiliki semua barang yang ia butuhkan. Maka dari itu, kegiatan pinjammeminjam sudah menjadi bagian yang tidak asing dalam kehidupan bermasyarakat di dunia ini. Disamping itu, Islam adalah agama yang sangat memperhatikan segala kebutuhan umatnya serta mengatur segala aspek kehidupan manusia.

Manfaat dalam pembiayaan menggunakan akad Qardh yang diterapkan dalam Bank Wakaf Mikro antara lain: (1). Membantu nasabahnya ketika mendapatkan kesulitan dengan memberikannya dana talangan jangka pendek; (2). Membantu para pedagang kecil dalam mengembangkan usahanya; (3). Sebagai solusi alternatif dalam pengalihan pedagang kecil dari jeratan utanag dengan rentenir; (4). Meningkatkan loyalitas masyarakat dikarenakan pembiayaan dengan menggunakan akad qardh ini dapat memberikan manfaat pada masyarakat menengah kebawah. Selain itu, dalam pembiayaan dengan menggunakan akad Qardh juga mempunyai beberapa persyaratan yang harus dipenuhi antara lain seperti harus ada pihak

18 Wawancara dengan Ibu Lilis selaku Nasabah Bank Wakaf Mikro Amanah Berkah Nusantara pada tanggal 19 Mei Tahun 2019

19 Abdullah bin Muhammad ath-Thayyar, Ensiklopedi Fiqh Muamalah dalam Pandangan 4 Maŗab, (Yogyakarta: Maktabah al-hanif, 2009) h. 153.

20 Mardani. Aspek. Hukum Lembaga Keuangan Syariah di Indonesia, (Jakarta: Kencana, 2015), h. 55. 
yang meminjamkan pinjaman (muqtaridh); harus ada pihak yang memberikan pinjaman (muqridh); harus ada objek dari akad tersebut yakni pinjaman yang dipinjamkan oleh pemilik dana kepada pihak yang menerima pinjaman dana tersebut; harus ada ijab qabul (sighah) yakni perkataan yang diucapkan oleh pihak penerima pinjaman dimana perkataan tersebut menunjukan suatu kebolehan untuk mengambil manfaat dari pihak penerima pinjaman. ${ }^{21}$

Bank Wakaf Mikro Amanah Berkah Nusantara di Pondok Pesantren Al Hidayah Karang Suci menggunakan pembiayaan dengan akad qardh dimana transaksi peminjaman dana tidak dikenakan bunga. Nasabah hanya diwajibkan untuk mengembalikan dana yang dipinjam pada waktu yang sudah ditentukan dan dapat utang tersebut dapat diangsur. Pembiayaan yang dilakukan oleh Bank Wakaf Mikro tidak mengharuskan adanya jaminan pada nasabahnya. Oleh sebab itu, nasabah merasa dimudahkan dengan didirikannya sebuah lembaga Bank Wakaf Mikro.

Adapun skema pembiayaan dengan menerapkan akad qardh pada Bank Wakaf Mikro penulis sajikan sebagai berikut:

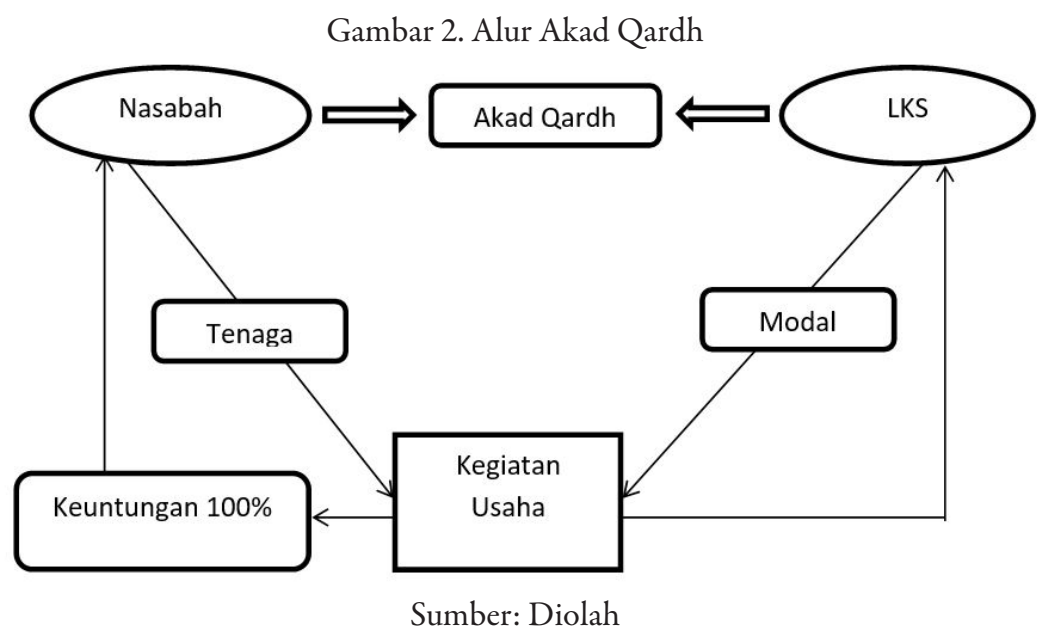

Dalam skema pembiayaan dengan menggunakan akad Qardh dalam Bank Wakaf Mikro tersebut dapat dijelaskan bahwa kontrak perjanjian Qardh dilakukan antara Bank Wakaf Mikro dengan nasabahnya. Kemudian nasabah akan menyediakan tenaganya untuk mengelola kegiatan usaha yang dimilikinya dan Bank Wakaf Mikro akan memberikan modal sebagai investasi. Modal tersebut

21 Wawancara dengan Ibu Ani selaku Nasabah Bank Wakaf Mikro pada Tanggal 30 Agustus Tahun 2019 
berasa dari dana yang dimiliki oleh Bank Wakaf Mikro dan dana kebajikan yang telah dikumpulkan oleh Bank Wakaf Mikro yang berasal dari Lembaga Amil Zakat Nasional Bank Syariah Mandiri Umat (LAZNAS BSM Umat). Dana tersebut merupakan dana wakaf atau hibah yang diberikan oleh donatur (waqif) agar dana yang didonasikan tersebut dapat dikelola secara produktif. Donasi tersebut berupa wakaf uang yang akan disalurkan pada Bank Wakaf Mikro guna memberdayakan masyarakat dalam bentuk pembiayaan. Selanjutnya bila dalam hal ini terdapat keuntungan, maka keuntungan akan diberikan oleh nasabah seluruhnya (100\%), tidak dibagi hasil oleh Bank Wakaf Mikro. Kemudian jika pembayaran telah jatuh tempo, maka nasabah akan mengembalikan modal seluruhnya sebesar $100 \%$ yang berasal dari Bank Wakaf Mikro tanpa ada tambahan sedikitpun.

Pembiayaan dengan akad Qardh yang digunakan oleh Bank Wakaf Mikro Amanah Berkah Nusantara dilakukan secara berkelompok, dalam setiap kelompoknya terdapat 5 (lima) orang anggota. Dalam proses pencairan dananya, pembiayaan ini dilakukan dengan pola 2-2-1 dimana dalam hal ini mempunyai maksud guna memprioritaskan kepada nasabah yang lebih membutuhkan dana tersebut. Dengan diterapkannya pembiayaan Qardh pada Bank Wakaf Mikro, bukan hanya untuk memberikan bantuan kepada masyarakat kurang mampu yang bertempat tinggal disekitar pondok pesantren saja, tetapi disamping itu juga diharapkan dapat mempererat hubungan silaturahmi antar nasabahnya. Hal ini didasari karena pembiayaan Qardh ini menggunakan sistem tanggung renteng, dimana apabila terdapat nasabah yang berhalangan hadir pada saat diadakannya pertemuan HALMI, maka angsurannya ditanggung oleh anggota yang lainnya.

Dewan Syariah Nasional Majelis Ulama Indonesia (DSN-MUI) juga mengatur ketentuan mengenai Qardh melalui Fatwa No. 19/DSN-MUI/XI/2000 yang menyebutkan bahwa;

1. Sumber dana qardh dapat berasal dari modal Lembaga Keuangan Syariah, keuntungan yang disisihkan oleh Lembaga Keuangan Syariah, serta lembaga lain yang memberikan dana kebajikan kepada Lembaga Keuangan Syariah.

2. Pinjaman diberikan kepada nasabah yang memerlukan. Mengingat bahwa target sasaran Bank Wakaf Mikro adalah masyarakat kecil dan menengah yang produktif yang berada di sekitar lingkungan Pondok Pesantren.

3. Pengembalian dana dilakukan pada waktu yang telah disepakati bersama dan jumlah pengembaliannya adalah sebesar dengan jumlah pokok pinjaman. Namun jika nasabah mengembalikan dananya lebih maka itu sifatnya adalah sukarela. Apabila nasabah tidak dapat mengembalikan dana pinjaman sesuai dengan batas waktu yang telah ditentukan bersama maka dapat diperpanjang 
jangka waktunya bahkan dapat dihapuskan sebagian atau seluruh pinjaman yang telah diberikan.

4. Nasabah dapat dikenakan biaya administrasi, sehingga biaya administrasi tersebut bukan bagian dari tambahan pokok pinjaman yang telah diberikan.

5. Jika diperlukan, maka dapat dimungkinkan adanya jaminan.

Nasabah dapat dikenakan sanksi apabila tidak mematuhi ketentuan seperti yang telah disebutkan dalam Fatwa MUI diatas, yakni:

1. Jika nasabah tidak mempunyai itikad baik untuk mengembalikan dana yang telah dipinjam sepanjang bukan karena ketidakmampuannya dalam mengembalikan besaran dana yang telah dipinjam, maka dalam hal ini dapat dijatuhkan sanksi.

2. Apabila antara pihak Bank Wakaf Mikro dan nasabah tidak menemui kesepakatan yang telah dilakukan melalu musyawarah bersama, maka penyelesaian sengketa pembiayaan qardh dapat diselesaikan melalui Badan Arbitrase Syariah.

Pembiayaan pada Bank Wakaf Mikro sebenarnya sama seperti Bank Syariah, namun yang membedakan yaitu terletak pada awal transaksinya. Transaksi awal yang digunakan oleh Bank Wakaf Mikro yaitu dengan pembiayaan menggunakan akad qardh. Apabila dalam pembiayaan akad qard dinyatakan sudah tuntas, maka dapat menggunakan akad lain sesuai dengan prinsip syariah yang telah ditentukan dalam peraturan perundang-undangan seperti misalnya akad mudharabah, musyarakah dan lain-lain. Model pembiayaan Bank Wakaf Mikro dilakukan secara berkelompok, dalam setiap kelompoknya minal terdapat 15 (lima belas) nasabah dan maksimal 20 (dua puluh) nasabah. Saat ini Bank Wakaf Mikro masih hanya fokus pada 1 (satu) Kecamatan di dalam proses pengelolaannya.

Bank Wakaf Mikro disamping sebagai lembaga keuangan syariah yang mempunyai fungsi guna menyalurkan pembiayaan kepada pelaku-pelaku usaha mikro dengan menggunakan prinsip akad Qardh, berdirinya Bank Wakaf Mikro juga memberikan suatu layanan pendampingan usaha yang akan diberikan oleh nasabah pembiayaan mikro. Oleh karena itu, berdiriya Bank WakafMikro diharapkan akan memberikan suatu dampak positif pada masyarakat terutama pemberdayaan masyarakatnya yang berada di sekitar pondok pesantren. Keberadaan Bank Wakaf Mikro inilah yang merupakan bentuk konkrit dari OJK untuk melawan rentenirrentenir dan agar dapat memberdayakan masyarakat khususnya di lingkungan pondok pesantren melalui pembiayaan yang produktif.

Kegiatan usaha yang dilakukan oleh Bank Wakaf Mikro Amanah Berkah Nusantara yang berprinsip pada syariah yaitu pembiayaan dengan Qard merupakan 
suatu pembiayaan bagi modal usaha dengan skala mikro dengan biaya jasa operasional mencapai $2,5 \%$ sampai dengan $3 \%$ dalam satu tahun dan tanpa agunan. Nasabahnya dapat mengangsur secara mingguan. Jumlah besaran pembiayaannya dilakukan secara berkala dan dibatasi mulai dari Rp. 1000.000 (satu juta rupiah) sampai dengan Rp. 3000.000 (tiga juta rupiah). Dalam melakukan kegiatan usahanya dengan berpedoman sesuai dengan prinsip-prinsip syariah maka telah dibentuk Dewan Pengawas Syariah (DPS) guna mengawasi dan memberi nasihat kepada Bank Wakaf Mikro agar kegiatan usaha yang dilakukannya tidak bertentangan dengan prinsip-prinsip syariah, disamping itu Dewan Pengawas Syariah (DPS) juga bertugas untuk menilai berbagai aspek sebagai pedoman operasional yang telah ditetapkan oleh DSN-MUI. Hal ini sesuai dengan aturan pada Pasal 13 ayat (1) Undang-Undang Nomor 1 Tahun 2013 tentang Lembaga Keuangan Mikro dimana dalam pasal tersebut menjelaskan bahwa dalam melakukan kegiatan usahanya dengan berpedoman pada prinsip syariah, Lembaga Keuangan Mikro diwajibkan untuk membentuk Dewan Pengawas Syariah. Selain itu, dalam melakukan pengembangan usahanya, Lembaga Keuangan Mikro Syariah yang berbasis pondok pesantren dalam mempunyai 7 (tujuh) prinsip program-program yang merupakan suatu nilai-nilai dalam melaksanakan program tersebut, yaitu: (1). Pemberdayaan masyarakat miskin atau kurang mampu; (2). Pendampingan yang diberikan harus sesuai dengan Prinsip Syariah; (3). Kerjasamanya dilakukan dengan pembiayaan kelompok atau sering disebut dengan (Ta'awun); (4). Memberikan suatu kemudahan (Sahl); (5). Amanah; (6). Program keberlanjutan; (7). Terkandung suatu keberkahan didalamya.

\section{Simpulan}

Bank Wakaf Mikro sebagai Lembaga Keuangan Mikro Syariah dimana kegiatannya berfokus pada pembiayaan, pengembangan usaha dan pemberdayaan masyarakat kecil produktif yang berada di lingkungan Pondok Pesantren yang diawasi oleh OJK yang berkoordinasi dengan pondok pesantren, perangkat desa, serta pemerintah daerah setempat. Bank Wakaf Mikro hanya menyalurkan dana, tidak melakukan kegiatan penghimpunan dana, mekanisme pembiayaannya berbasis kelompok dan imbal hasil yang didapat sebesar 3\% tanpa agunan. Transaksi dalam lembaga keuangan syariah harus menggunakan akad yang sesuai dengan nilai-nilai syariah. Dalam Peraturan OJK No. 62/POJK.05/2015 menyebutkan bahwa akadakad yang bisa digunakan dalam Lembaga Keuangan Mikro Syariah adalah akad mudharabah, musyarakah, murabahah, ijarah, salam, isthisna, ijarah muntahiya bittamlik dan qardh. Model pembiayaan yang digunakan pada Bank Wakaf Mikro 
Amanah Berkah Nusantara yakni akad Qardh. Dengan diterapkannya pembiayaan dengan menggunakan akad Qardh, diharapkan dapat menambah pendapatan dan laba di sektor usaha mikro, kecil dan menengah. Selain itu dapat mendorong para anggotanya untuk membayar zakat, membayar sedekah, menyisihkan uang guna ditabung serta meningkatkan sisi religiusitas. Oleh karena itu, pembiayaan dengan menggunakan akad Qardh dianggap efektif dalam upaya pengentasan kemiskinan.

\section{Daftar Pustaka}

\section{Buku}

Mardani. Aspek Hukum Lembaga Keuangan Syariah di Indonesia. Jakarta: Kencana, 2015.

Rahardjo, Satcipto. Ilmu Hukum. Bandung: Alumni, 1996.

Sugiyono. Metode Penelitian Kualitatif, Kuantitas, RङD. Bandung: Alfabet, 2018. Sutopo, H. B. Metodologi Penelitian Hukum KualitatifBagian II. Surakarta: UNS Press, 1998.

\section{Artikel}

Disemadi, H.S, \& Wahyuni, R.A.E. "Eksistensi Dan Kebijakan Regulasi Perizinan Lembaga Keuangan Mikro Oleh Otoritas Jasa Keuangan”, Vol.3, No.2, Tahun 2019.

Disemadi, H.S., \& Roisah, K. "Kontrak Build Operate Transfer Sebagai Sarana Mewujudkan Kesejahteraan Rakyat”. Jurnal Komunikasi Hukum, Vol.5, No.2, Tahun 2019.

Ernawan, D. A, dan Gustani. "Wakaf Tunai sebagai Sumber Alternatif Permodalan Lembaga Keuangan Mikro Syariah di Indonesia." Journal of Islamic Economics Lariba. Vol. 2, No. 1, 2016.

Faujia, A. "Bank Wakaf Mikro dan Pengaruhnya terhadap Inklusi Keuangan Pelaku Usaha Kecil dan Mikro (UKM).” $2^{\text {nd }}$ Proceedings Annual Conference for Muslim Scholars. 2018.

Fuadi. N. F. Z. "Wakaf Sebagai Instrumen Ekonomi Pembanøunan Islam." Iurnal Ekonomi Islam, Vol. 9, № 1, 2018. 
Mahat, M. A, Jaaffar, M. Y, dan Rasool, M. S. A. "Potential of Micro-Waqf as an Inclusive Stratagy for Development of Nation." Procedia Economics and Finance, 2015.

Medias, F. "Bank Wakaf: Solusi Pemberdayaan Sosial Ekonomi Indonesia." Indonesian Journal of Islamic Literature and Muslim Society. Vol. 2, No. 1, 2017.

Rusydiana, A. S. \& Irman Firmansyah. "Strategi Pengembangan Lembaga Keuangan Mikro Syariah di Indonesia: Pendekatan Matriks EFAS IFES.” Jurnal Ekonomi Islam, Vol. 9 No. 1, 2018.

\section{Peraturan Perundang-Undangan}

Undang-Undang No. 41 Tahun 2004 tentang Wakaf

Undang-Undang No. 1 Tahun 2013 tentang Lembaga Keuangan Mikro

Peraturan Otoritas Jasa Keuangan (OJK) No. 62/POJK.05/2015

Peraturan Bank Indonesia No. 7/46/PBI/2005 tentang Akad Penghimpunan dan Penyaluran Dana bagi Bank yang Melaksanakan Kegiatan Usaha berdasarkan Prinsip Syariah 